DOI: https://doi.org/10.31933/dijemss.v2i2

Received: 23 September 2020, Revised: 25 November 2020, Publish: 20 December 2020

\begin{tabular}{|c|c|c|}
\hline DINASTI & $\begin{array}{l}\text { DIJEMSS } \\
\text { DINASTI INTERNATIONAL JOURNAL } \\
\text { OF EDUCATION MANAGEMENT AND } \\
\text { SOCIAL SCIENCE }\end{array}$ & $\begin{array}{r}\text { https://dinastipub.org/DIJEMSS } \\
\text { editor@dinastipub.org } \\
08117401455\end{array}$ \\
\hline
\end{tabular}

\title{
THE TRANSFORMATION STRATEGY AND SAFETY IMPLEMENTATION OF CULTURE CHANGE AT PT PERTAMINA DRILLING SERVICES INDONESIA
}

\author{
Muhammad Arifin', Chaerudin ${ }^{2}$ \\ ${ }^{1)}$ Mercu Buana University, Jakarta, Indonesia, ariefin_0716@yahoo.com \\ ${ }^{2)}$ Mercu Buana University, Jakarta, Indonesia, chaerudin18@gmail.com
}

Corresponding Author: Muhammad Arifin

\begin{abstract}
This research had purposed to analyzed those Transformation Strategy and Safety Implementation of Culture Change in improving the Occupational Safety and Health from PT Pertamina Drilling Services Indonesia during period 2015-2020. These research data was result from in-dehpt, interview, FGD, primary and secondary data from PT Pertamina Drilling Services Indonesia during these implementation of HSE Work culture change program during period of 2015-2020. Research method used qualitative with type of case study research. Data analysis used Mckensy 7S Framework and The results showed that PT Pertamina Drilling Services Indonesia has a strategic plan for any kind of transformation from HSE Work culture until 2030 through "Salam Lima Jari" program. Through planned and systematic program until 2020, PT Pertamina Drilling Services Indonesia has succeeded in putting HSE Work culture at Proactive level. The ability of PT Pertamina Drilling Serrvices Indonesia to create strategic planning and implement HSE programs should be encouraged by ability to strengthen system and program integration within organization. The Succeed of HSE culture will achieved if there has supported by consistent commitment from management and all related units in established HSE culture as the main lifestyle at organization therefore HSE culture did not stop at cognitive and psychomotor aspects of employees but also its holistically becomes an effective organization.
\end{abstract}

Keywords: Transformation Strategy, HSE Culture, Mc Kennsy 7S Framework, Organizational Performance.

\section{INTRODUCTION}

Natural Resources mining exploration business activities are important part of development. Exploration of Natural Resources causes various unwanted impacts, among others, which related to safety and environmental aspects. A work accident is an event which never expected by everyone because it could causing various losses ranging from material loss 
to death. In general, work accidents occurs because of these two things, such as unsafe behavior and unsafe conditions.

OHS Prevention is part of continuity these day-to-day business activities. Apart from need constant attention, effective action on occupational safety and health demands a joint commitment from workers and employers. The Occupational Safety and Health Management System is part of overall organizational management system which includes organizational structure, planning, responsibility, enforcement, assessing and maintaining OHS policies in context of controlling risks related to work activities to create a safe, efficient and productive workplace (Tarwaka, 2014). The goals and purposed from OHS Management System which written in article 2 of Government Regulation Number 50 of 2012 which concern about those Implementation from OHS Management System, Which is to create an OHS system at workplace by involving an elements of management, labor, conditions and an integrated work environment in order to prevent and reduce an accidents and diseases due to work and creation of a safe, efficient and productive workplace (Tarwaka, 2014).

PT Pertamina Drilling Services Indonesia (PDSI) is a subsidiary from PT Pertamina (Persero) which engaged in exploration and exploitation of oil and gas and geothermal drilling. PT Pertamina Drilling Services Indonesia had applience of corporate governance principles to maintain the trust of customers, shareholders, business partners and other shareholders. These implementation of corporate governance was supported by continuous improvement of human resource competencies as a form of implementing corporate social responsibility in order to produced superior future generations. Pertamina Drilling Services Indonesia has strong policy related to occupational health and safety in company environment. One of these policies are written by Quality, Health, Safety, Security and Environmental (QHSSE) Policy.

Pertamina Drilling Services Indonesia's commitment to anticipating all forms of work risk that earned " Salam 5 Jari "Program which launched in May 2015 to address issues related to QHSSE aspects at PT Pertamina Drilling Services Indonesia. To ensure the success of these "Salam lima jari" program, PDSI is increasingly active in cultivating QHSSE within the company. To increase these awareness of Pertamina Drilling Services Indonesia employees in implementing QHSSE / OHS it is necessary to instill the safety culture. the approach process in improving safety, health and environment requires a variety of strategies and visionary also innovative leadership in creating an OSH culture and a safe working environment at Pertamina Drilling Services Indonesia.

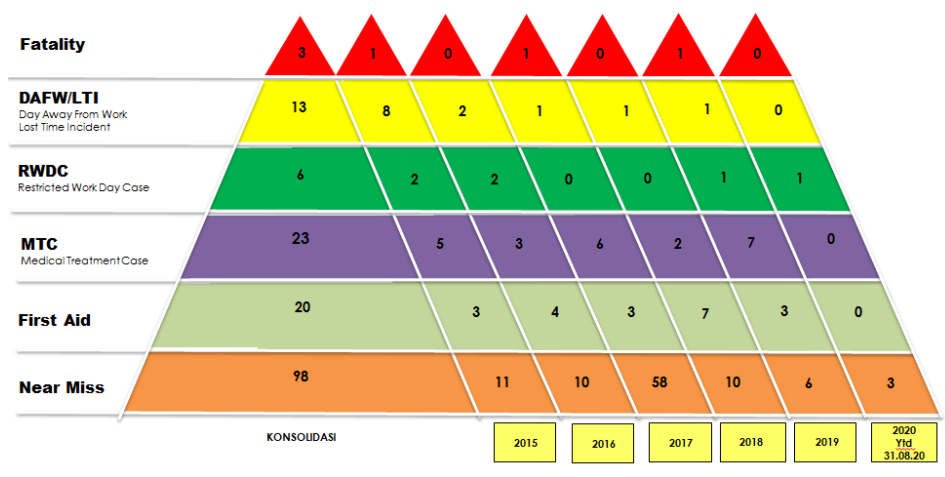

Figure 1. HSE Performance of PT Pertamina Drilling Services Indonesia

Source: Processed company data 
PT Pertamina Drilling Services Indonesia's Key Performance Indicators (KPI) shows the extraordinary progress of the implementation of OHS in its company. From those table above, it can be seen that if all workers always prioritize OHS aspects as a culture, then zero accident target will automatically be created. Then safety leadership character that a leader should have then Pertamina Drilling Services Indonesia would succeed in established these OHS culture.

Considered these statement above, in examine these cultural transformation processed of QHSSE/MK3N at Pertamina Drilling Services Indonesia, the author will carried out these research with tittle "The Transformation Strategy and Safety Implementation of Culture Change at PT Pertamina Drilling Services Indonesia".

\section{LITERATURE REVIEW Organizational Culture}

Organizational culture has the meaning as a system which held by the members of organization, which consists of basic assumptions and values that distinguish the organization from other organizations, which are socialized to each member as their way or perception of thought and behaving as well as hope that other people in organization will behave in the same way as them. According to Schein (2014) organizational culture used as a system of understanding in acts and becomes guides for all employees that differentiates one organization to others as well as a common pattern of assumptions which have been research by group members in solving problems and for the benefit of external adaptation and internal integration.

\section{Work Process}

Work process is defined as a method, tactics and technique related to actual resources (labor, machinery, subtances and materials) need to changed in order to obtain a result. Every work process always contained certain potential hazards if its not received those special attention which could causing work accidents. The main cause of work accidents in work process is human factors, known as unsafe actions and environmental factors, that to be called as unsafe conditions (Tarwaka, 2014:10-23).

\section{Work Accident}

According to Regulation of the Minister of Manpower of Republic of Indonesia number PER.03/MEN/1998, work accident is an unwanted and unexpected incident that could causing human and property casualties. In these implementation, work accidents in industry could be divided into 2 (two) main categories, which is industrial accidents and accidents which occur outside the workplace. An accident is a series of events caused by interrelated factors or potential hazards (Tarwaka, 2014:11).

\section{Behavior Based Safety}

Behavior based safety is a system that companies use to change unsafe employee behavior and attitudes. According to Geller (2001) in Saodah (2015), behavior based safety is approaching process to improving occupational health and environmental safety by helping group of workers identify behaviors related to OHS. Furthermore, Straub (2005:32) in Saodah (2015:28) has defined that behavior based safety will educate its employees to find the root that causing these troubled accidents behaviour

\section{The Process of Implementing Behavior Based Safety}


The most important elements in a process will also have an impact on the successful implementation of safe behavior. These components which involved in implementing safe behavior such as: identification of at-risk behavior; development of an appropriate observation checklist; teachs everyone as observers in making observations; continuous safe behavior assessment; ; feedback; arouse the spirit of involvement in behavior based safety activities, it is necessary to give awards to individuals and teams. There are many variations of approaches that could be done in implementing behavior based safety, but it all depends on the objectives in implementation. At the beginning of implementation of this program, the management should approved towards achievement targets and find out the reference per period, then targets achievement for worker safe behavior becomes the custom in implementing those safety observation program.

\section{Behavior Based Safety Approach to Reduce Unsafe Behavior}

According to Cooper, et al (2011) in identifying, there are criteria that are very important for implementation these BBS program, which is: Involving Employee Participation Based on Participatory Approach; Focusing Specifically on Unsafe Behavior; Based on Observation Result Data; and the Decision Making Process. Based on the evolution of OHS performance, OHS has evolved over time and changes in behavior. For this reason, the world's OHS experts have begun to focus on efforts to improve performance with OHS behavior change programs which could ultimately improve OHS culture so the incidence rate could be reduced (Somad, 2013:143).

\section{Change Management}

According to Bennet P. Lientz (2014), change management is an approachment to planning, designing, implementing, managing, measuring and maintaining change in work and business processes. Some of the activities related to change management are: Reviewing the triggers and expectations of change; Identifying potential areas for change; Defines the purpose and scope of change; Defining activities for change; Defines how work is done after changes; Determine the implementation strategy of the changes; Manage and direct change; Measure work before, during and after changes; and Manage its momentum.

\section{Change Management Methods}

There are various methods of change management, the method of change management used in this research was Anderson version and Anderson Nine Phase Change Process Model. This method contained nine steps of change. Each step consists of several activities and tasks which according to plan, design and implement change (Anderson, et al., 2011).

\section{The McKinsey 7S Model}

The basic idea of this model is seven internal aspects or elements of the organization. The seven elements are categorized as "hard" elements and "soft" elements. "Hard" elements are easy to define, on the other hand, "soft" elements are more difficult. These elements include strategy, structure, style, system, staff, skills, and shared values. (Singh, 2013).

\section{Theoretical Framework}

This research will study and explore these strategy of implementing BBS in organization which engaged in oil and gas mining using Anderson's idea of cultural transformation 
(Anderson, 2013) with several stages that summarized in these following theoretical framework:

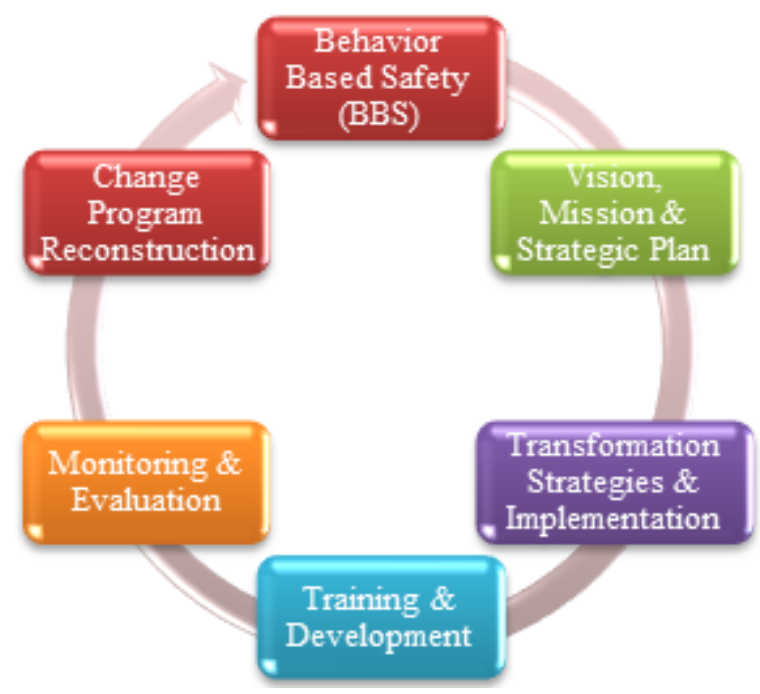

Figure 2. Theoretical Framework

Company's vision, mission and strategic plan are basis to determining these pattern and strategy for transformation and implementation of work safety culture. Training and development used as a penetration instrument. System and model for program monitoring and evaluation are needed to measure effectiveness of this programs. This cycle will produce new construction strategies and models for implementing safety culture changes maximally and effectively.

\section{RESEARCH METHODS}

These research method used qualitative research method that used to examine conditions of its natural objects, where the researcher is the key instrument, the data collection technique was carried out by triangulation (combined), the data analysis was inductive and these qualitative research results emphasize meaning rather than generalization. Sugiyono, 2014). Beside by using qualitative research methods, this research was carried out by case study approach, which in form of in-depth research on aspect from social environment including humans. In this research, the researchers used three stages of data analysis, which consisting of analysis when collecting data, analysis after data collected and the last one is analyzing case study data. In this research, the researchers used technique to check validity of data triangulation with sources and triangulation with data.

\section{FINDINGS AND DISCUSSION \\ Research Result}

These research results were coding from field findings through in-depth interviews and FGDs with key informants, namely: VP HSSE \& Quality, VP Human Capital, HC Development Manager and HSE Manager as well as a collection of internal company data on the implementation of HSE culture at PT Pertamina Drilling Services Indonesia since 2015. until 2020 which are processed thematically. 
VP HSSE \& Quality PT. Pertamina Drilling Services Indonesia when interviewed by researchers regarding the HSE transformation policy explained, as an international standard company and regional market leader in the field of oil and gas and geothermal drilling, in carrying out social responsibility on field of occupational health and safety in an integrated manner in the Quality, Health program, Safety, Security \& Environment (QHSSE) to increase operational efficiency and productivity. Further explanation was given by the VP HSSE \& Quality of PT Pertamina Drilling Services Indonesia regarding these implementation of QHSSE which is real implementation in every operational activity of the company. Pertamina Drilling Services Indonesia considers QHSSE as a form of responsibility that supports the acceleration of employee performance. VP Human Capital of PT Pertamina Drilling Services Indonesia was emphasized that operational activities which carried out by QHSSE were according to work system and procedure as well as the Work Program that had been compiled and documented were based on the existing Work System.

VP Human Capital's explanation related to HSE policy that operational aspects and QHSSE are vital aspects that determine the sustainability of a company, especially companies that engaged in services. This were also quoted in RJPP (Corporate Long Term Plan) of PT Pertamina Drilling Services Indonesia during 2015-2019. In RJPP and its Initiative Program, occupational safety is a top priority in running a business. Beside that, program were carried out according to QHSSE Policy which contained of six commitments, which is compliance, skill, prevention, self, harmony, and innovation.

Various kinds of cultural development activities include programs that leading activities aimed at managing risks related to QHSSE aspects so safety, healthy, and friendly environment could be formed. These implementation of QHSSE program in 2016 were also aims to increase the involvement of all people in the company related to safety aspects then all parties were realized that QHSSE aspect is a shared responsibility in order to achieve the company set targets

HSE Manager were also explained that to fix the Company's QHSSE performance in 2015 a breakthrough program was launched related to the QHSSE aspect with entitled "SALAM LIMA JARI" which represents the management support of PT Pertamina Drilling Services Indonesia to all employees and partners within PT Pertamina Drilling Services Indonesia. to use the stop work authority if their find a dangerous condition then the accidents could be prevented as early as possible. In addition to background by Safety Performance, the QHSSE program were derived from HSE culture survey result which conducted in May 2015, the survey has refers to measurement guide for Pertamina's HSE Culture, Directorate General \& HR, February 5, 2010. The survey shows that PT Pertamina Drilling Services Indonesia still "reactive" in facing problems related to QHSSE aspects.

As a continuation and success of the program related to QHSSE aspects of PT Pertamina Drilling Services Indonesia with "SALAM LIMA JARI" in 2015, PT Pertamina Drilling Services Indonesia has developed another program related to this leading activity to more comprehensive stage with the launch of " SALAM LIMA JARI" Phase II Program in February 2016. To ensure the program is run consistently, in 2017 the SALAM LIMA JARI Phase II (Bridge) Program was launched, which includes Management Commitment; Quality to Profit; Behavior Based Safety; Green Drilling, and Security for All. 
Pertamina Drilling Services Indonesia's management has committed to implementing QHSSE as outlined in a number of activities including: Management Walkthrough, Management HSE talk / sharing, HSE meetings, Incident action tracking, HSE Personal Leading and Incident accountability broadcasting.

To improve QHSSE performance, Pertamina Drilling Services Indonesia has adopted a culture change approach. The program launched was focused in changing tbehavior of all personnel that involved in Company's operational activities. Some of the programs were implemented include: HSE Marshal for Behavior, HSE Award \& Consequencies, Learning From Event, Drop Object Management, New JSA \& Permit to Work, Recruiting Development for Local Labor, Job Personal Competency, Pertamina Drilling Services Indonesia HSE Passport, Camera on Spot (COS) Program, HSE Campaign, Stop Work Authority, Contractor Safety Management System, and Lifting Plan Implementation.

In Green Drilling program at Pertamina Drilling Services Indonesia that collaborated with third parties on handling the toxic and waste that generated from operational activities. This third party manages oil based on permit from the Ministry of Environment. The management of liquid toxic and waste (used oil) that produced by operational activities has been regulated in a policy issued by the President Director, namely collaborating with third parties who already have permits to collect, transport and treat used oil waste issued by the Ministry of Environment. Thus, not all parties can access the waste management of used oil from the rig's operational activities. Apart from handling waste, for the environmental conservation program there are 3 (three) activities carried out by PT Pertamina Drilling Services Indonesia in this Phase II Salam Lima Jari program, including Waste to added value, Thousand Trees For Drilling, Green Electricity and Quality To Profit

Programs related to the security aspects of the 2015 Salam Lima Jari program include Strengthening Non-Physical Security through the preparation and issuance of TKO for NonPhysical Security 058 / DSI0000 / 2015-S0, Strengthening Information Security Confidentiality Security through TKO for Securing the Confidentiality of Company Information No.B-062/DSI0000/2015-S0 and restrictions on the use of desk telephone facilities with the use of Individual PINs, Early Information Security Interference through initiation of information dissemination systems related to traffic conditions.

\section{Data Analysis}

From these research results above, data analysis was carried out by MCkinsey 7S Framework approach so the all questions in these research would have an answered. PT Pertamina Drilling Services Indonesia in implementing QHSSE used an integrated strategy for structured and systemic Quality, Health, Safety, Security \& Environment program to increase operational efficiency and productivity. This integration was contained in RJPP (Company Long Term Plan) at PT Pertamina Drilling Services Indonesia with Safety as Priority, which includes specific programs for Leadership Involvement, Personal Awareness \& Competencies Improvement, Salam Lima Jari Phase two Program and QHSSE Policy.

PT Pertamina Drilling Services Indonesia developed programs related to these leading activity efforts to more comprehensive stage with the launch of "SALAM LIMA JARI Phase II" (Bridge) with a larger number of programs and integrated as ones. "SALAM LIMA JARI Phase II" (Bridge) Program were includes: 1. Management Commitment; 2. Quality to Profit; 3. Behavior Based Safety; 4. Green Drilling and 5. Security for All. The implementation of PT 
Pertamina Drilling Services Indonesia's HSE culture were also supported by the formation of structure which could encourage the implementation of an effective and efficient HSE culture transformation. The implementing of HSE culture was led by BOD and operationally carried out by HSE Department. Pertamina Drilling Services Indonesia create an special team to review and evaluate Work Procedure System (STK) and existing organizations to ensure the availability and compliance of existing work procedures in the company, then to carry out socialization of Work Procedure system which been passed from reviewed or revised through internal functions meetings and initial meetings prior to implementation those work in the field.

Safety leadership at PT Pertamina Drilling Services Indonesia used participatory direction leadership model in implementing the HSE culture implementation program. By this leadership style, in addition to being bureaucratic, PDSI management were also participatory in the process of changing the HSE culture as seen in the Management Walk Through program, Management HSE Talk/Sharing, HSE Meeting and HSE Personal Leading. The leadership style in HSE culture transformation process was carried out according to QHSSE Policy which contained six commitments as shared values that should be obeyed by all Pertamina Drilling Services Indonesia personnel which is, Obedience, Skill, Prevention, Self, Harmony, and Innovation.

The "Safety Culture Change" transformation at PT Pertamina Drilling Services Indonesia were also supported by development of its HR competencies (knowledge, skills and attitude) by creating a talent management program. Through these Human Capital function,plan and carry out training and development programs which relevant to the needs of HR and the Company on an ongoing basis to ensure that HR within the company has competencies which in line with the demands of an increasingly complex position and business.

Pertamina Drilling Services Indonesia also discover Building Internal Competencies as part of the Main Initiative Program run by the Company. This program contained the Company's commitment to align employee competencies with the Company's business strategy, optimize knowledge sharing, fill competency gaps through internal training/in-house training, and standardize HR development in the Company. Several types of training programs that carried out at PDSI include Mandatory Training, Technical Training, General Training and HSSE Training Programs.

Monitoring and evaluation system at PT Pertamina Drilling Services Indonesia's "Safety Culture Change" transformation strategy was carried out in measured and systemic manner through programs such as Management Walk Through, Management HSE Talk/Sharing, HSE Meeting and HSE Personal Leading Drop Object Management, Camera On Spot (COS), Audit and Measurement of HSE Culture and QHSSE Management Audit and Assessment

The obstacles and challenges for the "Safety Culture Change" transformation process at PT Pertamina Drilling Service Indonesia are the program evaluations both during and at the end of the year it is identified that there still a backlog, especially in terms of: competence, leadership and behavior. In addition, for the worker level there is no formal inspection system on HSE aspects, no job safety analysis has been made and HSE procedures are incomplete and only focus on what is considered to be the most important.

The Implementation at the level of work partners will triggered a perception that HSE Meetings are waste of time and seems to be formality. No job safety analysis has been made and if an incident occurs, the workers who are directly involved in the field are directly 
blamed, regardless the root of the problem. Likewise, the implementation of CSMS at PDSI has only been implemented properly at administrative stage (Risk Assessment, PreQualification, and Selection), while the implementation stage (Pre Job Activity, Work In Progress, and Final Evaluation) still requires improvement, especially the involvement of owner/user contract on its implementation.

\section{Discussion}

HSE Culture building program at PT Pertamina Drilling Services Indonesia is not an easy thing to achieve. Convincing about safety on workers it does similiar as convincing workers to believe in the existence of heaven and hell, about rewards and sins which still an abstract. The ability of PT Pertamina Drilling Services Indonesia to make strategic planning and implement HSE programs should be encourage by the ability to strengthen system and program integration within organization. The success of HSE culture will be achieved if it is supported by the consistent commitment of the management and related all parties in making the HSE culture as the main lifestyle in the organization.

PT Pertamina Drilling Services Indonesia should avoid an approach which focuses on HSE program on worker and sectoral levels so the actions taken will not make workers defensive and apply safety if supervised or just because they are afraid of getting punished.

PDSI HSE culture program based on incentives or rewards for achieving zero Incident, Man Hours Non-LTI, should not be the main driving factor because workers tend to cover up the accidents just to get the promised incentives.

The program to build an HSE Culture at PDSI is a continuous process in the long term with measurable stages in line with Industrial Safety \& Hygiene parameters. What is needed by PDSI was strengthening and upgrading the understanding from all members of organization on defining roles and responsibilities (Rule and Responsible). All departments or sections and levels of management regarding the roles and responsibilities from all the HSE culture. Strengthening the KPI HSE culture (key Performance Indicator) for each employee and organization need to improved so all the employees have an interest in achieving that safety performance

Strengthening commitment of these HSE culture to PDSI partners should not stop only in administrative aspect, but it should be able to encourage partners to be responsible for the actual of HSE culture. PDSI also needs to strengthen the responsibilities of partners through trust. By Building this trust would provide motivation or enthusiasm for all work partners in implementing these HSE culture program. This were in line with OSHA, work safety culture consisted of beliefs, practitioners, and attitude towards togetherness in a company. Culture is an atmosphere which created by beliefs, attitudes, and etc, that will be form as behavior.

\section{CONCLUSION AND SUGGESTION Conclusion}

According to these research results which has been done, these following conclusions could be described as follows: 
1) These transformation process and implementation from HSE culture at PT Pertamina Drilling Services Indonesia was carried out by strategic planning and implemented through measurable short, medium and long term programs

2) The safety leadership of PT Pertamina Drilling Services Indonesia is the formation of HSE culture. The commitment and exemplary leadership from PT Pertamina Drilling Services Indonesia is the most important factors in determining the success of building an HSE culture. Apart from being individualized, safety leadership at PT Pertamina Drilling Services Indonesia which has been institutionalized in company documents that play a major role in mobilizing participation also empowering all employees and organizational partners with the necessary resources and authority to find and fix problems in implementing the HSE culture.

3) The role and function from HR department of PT Pertamina Drilling Services Indonesia in "Safety Culture Change" is integrated process of HR strategic plan and HSE implementation programs.

4) Major problem that faced by PT Pertamina Drilling Services Indonesia is the existence of social facts that related to accommodate local workers who are actually local residents. Those Qualifications of safety aspect was various and most are at levels far below from minimum expected that requirements. Education and work background as well as understanding of HSE aspects always have a big gap with standards and culture which has been established. PT Pertamina Drilling Services Indonesia has always faced the problem of shaping an educating to local workers to work according to HSE standards and policies

5) Monitoring and evaluation system for transformation strategy and implementation at PT Pertamina Drilling Services Indonesia's "Safety Culture Change" had done through various reporting tools, meeting forums and detailed routine audits of HSE program. Employees feels comfortable when reporting those HSE safety issues. The level of participation is always high, which indicated that employees are highly motivated and take the initiative to promote the HSE culture program.

\section{Suggestion}

According to these research results from those analysis of the discussion and conclusions above, these several suggestions that could be address as complement for results of this research could be seen as follows:

1) PT Pertamina Drilling Services Indonesia, the person in charge of these HSE field needs to increase sufficient time on the field and increase the involvement of all components in implementing HSE culture. Promote a system of discipline and fair behavior for all employees. Corrective action and preventive action abilities which need to improved so the opportunities for its improvement were identified and resolved before problems occurred. Maintain and enhance visible leadership commitment at all levels in organization.

2) In HR Management learning, it is necessary to adding those specific HSE culture material because its inseparable part from measure performance and work culture.

3) Further research related to spiritual intelligence factors and local wisdom as strategy in accelerate these implementation of HSE culture that needs to be done.

\section{REFERENCE}

Anderson, L., \& Krathwohl, D. A. (2011). Taxonomy for Learning, Teaching and Assessing: A Revision of Bloom's Taxonomy of Educational Objectives. New York: Longman. 
Cooper, Donald R., \& Schindler, Pamela S. (2011). Business research methods (11th ed.). New York: Mc GrawHill/Irwin.

Lientz, Bennet P and Rea, Kathryn P. (2004). Breakthrough IT Change Management - How to Get Enduring Change Results. s.1. : Elseiver Butterworth Heinemann, 2004.'

Kementerian Ketenagakerjaan Repubik Indonesia. (1998). Peraturan Menteri Tenaga Kerja Republik Indonesia nomor PER.03/MEN/1998, Tentang Kesehatan dan Keselamatan Kerja.

Peraturan Pemerintah. (2012). Peraturan Pemerintah Republik Indonesia Nomor 50 Tahun 2012 Tentang Penerapan Sistem Manajemen Keselamatan dan Kesehatan Kerja.

Schein, Edgar H. (2014). Organizational Culture and Leadership. San Francisco: Josey-Bass Publishers.

Singh, A. (2013). A study of role of McKinsey's 7S framework in achieving organizational excellence. Organization Development Journal: Chesterland, 31(3), 39-50.

Somad, I. (2013). Teknik Efektif dalam Membudayakan Keselamatan \& Kesehatan Kerja. Jakarta: Dian Rakyat.

Sugiyono. (2014). Metode Penelitian Administrasi, dilengkapi dengan Metode R\&C. Alfabeta. Bandung.

Tarwaka. (2014b). Keselamatan dan Kesehatan Kerja; Manajemen dan Implementasi K3 di Tempat Kerja. Surakarta: Harapan Press. 